\title{
Effects of feeding hulled and hull-less barley with low- and high-forage diets on lactation performance, nutrient digestibility, and milk fatty acid composition of lactating dairy cows
}

\author{
Y. Yang, ${ }^{*}$ G. Ferreira, ${ }^{* 1}$ C. L. Teets, ${ }^{*}$ B. A. Corl, ${ }^{*}$ W. E. Thomason, $\dagger$ and C. A. Griffey $\dagger$ \\ *Department of Dairy Science, and \\ †Department of Crop and Soil Environmental Sciences, Virginia Tech, Blacksburg 24061
}

\begin{abstract}
The objective of this study was to evaluate lactation performance, nutrient digestibility, and milk fatty acid composition of high-producing dairy cows consuming diets containing hulled or hull-less barley as the grain source when feeding low-forage (LF) or high-forage (HF) diets. Eight primiparous $(610 \pm 40 \mathrm{~kg}$ of body weight and $72 \pm 14 \mathrm{~d}$ in milk) and 16 multiparous $(650 \pm 58 \mathrm{~kg}$ of body weight and $58 \pm 16 \mathrm{~d}$ in milk) Holstein cows were randomly assigned to 1 of 4 diets in a replicated $4 \times 4$ Latin square design with a $2 \times 2$ factorial arrangement of treatments and 21-d periods. Cows were assigned to squares based on parity $(1,2$, and $\geq 3$ ) and days in milk. Diets were formulated to contain on a dry matter basis (1) $45 \%$ forage and hulled barley as the sole grain source, (2) $65 \%$ forage and hulled barley as the sole grain source, (3) $45 \%$ forage and hull-less barley as the sole grain source, and (4) $65 \%$ forage and hull-less barley as the sole grain source. Dry matter intake tended to be lower for the diet with $65 \%$ forage and hulled barley than for the rest of the diets $(24.4$ vs. $26.6 \mathrm{~kg} / \mathrm{d})$. Neither the type of barley nor the forage-to-concentrate ratio affected milk yield $(41.7 \mathrm{~kg} / \mathrm{d})$. Barley type did not affect milk fat or protein concentrations. Feeding LF diets decreased milk fat concentration from $3.91 \%$ to $3.50 \%$. This decrease was less than anticipated and resulted in a $7 \%$ decrease in milk fat yield relative to cows consuming HF diets (1.60 and $1.49 \mathrm{~kg} / \mathrm{d}$ for HF and LF diets, respectively). Feeding LF diets increased the concentration of C18:1 trans-10 in milk fat, suggesting that feeding LF diets may have marginally altered rumen function. In conclusion, LF diets containing barley grains can marginally decrease milk fat concentration. Overall, and based on the conditions of this study, there is limited evidence to anticipate a dramatic or acute milk fat depression when
\end{abstract}

Received November 2, 2017.

Accepted December 5, 2017.

${ }^{1}$ Corresponding author: gonf@vt.edu feeding hull-less barley as the grain source in diets for high-producing dairy cows.

Key words: hull-less barley, hulless barley, cereal grain, milk fat depression

\section{INTRODUCTION}

Cereal grains, such as corn, sorghum, barley, wheat, and oats, are commonly included in rations for lactating dairy cows as an energy source (Herrera-Saldana et al., 1990). Cereal grains mainly comprise the pericarp that gives protection to the grain, the germ that will become the new plant after germination, and the endosperm that stores starch (McAllister and Cheng, 1996). Using the in situ ruminal disappearance technique, Herrera-Saldana et al. (1990) reported different starch disappearance rates among cereal grains; rates were faster for wheat and barley and slower for corn and sorghum. This observation is also supported by in vivo studies (Ferraretto et al., 2013).

Feeding rations containing readily fermentable starch can increase the production of lactic acid, therefore reducing ruminal $\mathrm{pH}$ (Silveira et al., 2007; Mohammed et al., 2010). Reduced ruminal $\mathrm{pH}$ can alter the pathways of fatty acid biohydrogenation by the microbes within the rumen, which may lead to milk fat depression through a reduction of de novo fatty acid synthesis within the mammary gland (Bauman and Griinari, 2003). As fibrous components ferment slower than NFC, a minimum concentration of dietary NDF is recommended to sustain ruminal and cow health (Mertens, 1997; NRC, 2001). Current recommendations from NRC (2001) suggest that dietary NDF should be increased when readily available starch sources, such as barley, replace dry ground corn in the diet (Beauchemin, 1991).

Yang et al. (2017) evaluated the use of hull-less or "naked" barley (Thomason et al., 2009; Griffey et al., 2010) as a grain source for feeding high-producing cows. For their study, the authors hypothesized that replacing corn with hull-less barley would decrease milk fat 
concentration as a consequence of a lower ruminal $\mathrm{pH}$ and a subsequent modification of the pathways of fatty acid biohydrogenation by the rumen microbes within the rumen (Mohammed et al., 2010). Although the dietary NDF concentration was lower than recommended for diets containing barley grain (30 vs. $34 \%$ NDF; Beauchemin, 1991; NRC, 2001), milk yield and milk fat concentration were similar between diets containing $100 \%$ corn grain or $100 \%$ hull-less barley as the grain source. Contrary to their expectations, the concentration of de novo fatty acids was also not affected by grain source (Yang et al., 2017).

Studies evaluating the inclusion of hull-less barley as an energy source in diets for lactating dairy cows are limited and have variable results (Beauchemin et al., 1997; Yang et al., 1997a,b, 2017). Under the scope that starch from hull-less barley is rapidly fermentable (Yang et al., 1997a), we hypothesized that rumen function is altered when cows are fed low-forage diets containing barley grains and that an altered rumen function would be reflected in lower lactation performance, a reduction of de novo fatty acids in milk fatty acid profile, or a combination of both. Therefore, the objective of this study was to evaluate lactation performance, nutrient digestibility, and milk fatty acid composition of high-producing dairy cows consuming diets containing hulled or hull-less barley as the grain source when feeding low-forage (LF) or high-forage (HF) diets.

\section{MATERIALS AND METHODS}

\section{Animals, Housing, and Diets}

All procedures involving animals were approved by the Institutional Animal Care and Use Committee of Virginia Tech (Blacksburg). Eight primiparous (610 \pm $40 \mathrm{~kg}$ of BW and $72 \pm 14$ DIM at the beginning of the experiment) and 16 multiparous $(650 \pm 58 \mathrm{~kg}$ of $\mathrm{BW}$ and $58 \pm 16$ DIM at the beginning of the experiment) Holstein cows were randomly assigned to 1 of 4 diets (Table 1 ) in a replicated $4 \times 4$ Latin square design with a $2 \times 2$ factorial arrangement of treatments and 21-d periods. Cows were assigned to squares based on parity $(1,2$, and $\geq 3)$ and DIM. Cows were housed in a 24-stall pen within a freestall barn and were fed once daily (1100 h) using a Calan gate system (American Calan Inc., Northwood, NH). Before beginning the experiment, cows were trained for a 2 -wk period to find their door.

Diets (Table 1) were formulated to contain (DM basis) $45 \%$ forage and hulled barley as the sole grain source (LFHD), 65\% forage and hulled barley as the sole grain source (HFHD), $45 \%$ forage and hull-less barley as the sole grain source (LFHS), and $65 \%$ forage and hull-less barley as the sole grain source (HFHS). Barley grains were obtained from 2 farms in Virginia (Charlotte and Westmoreland counties for hulled and hull-less barley, respectively). Barley cultivars were Thoroughbred (Virginia Crop Improvement Association, Mechanicsville, VA) and Amaze 10 (Virginia Identity Preserved Grains LLC, Charles City, VA) for hulled and hull-less, respectively. Both barley grains were ground using a $4.76-\mathrm{mm}$ screen on a hammer mill and incorporated into concentrate pellets at a commercial feed mill (Big Spring Mill Inc., Elliston, VA). All diets were formulated to meet requirements (NRC, 2001) for a 630-kg lactating dairy cow producing $42 \mathrm{~kg}$ of milk/d.

Concentrate pellets were mixed with corn silage and chopped alfalfa hay (Table 1) and delivered ad libitum $(\sim 5 \%$ refusals) as a TMR. Mixing and feeding was performed using a Calan Data Ranger (American Calan Inc.). The amount of feed offered and refused was measured daily. Cows were milked twice daily (0100 and $1300 \mathrm{~h}$ ), and milk weights were automatically recorded at each milking. The averages of daily milk yields and DMI from d 15 to 21 of each period were used for statistical analysis.

\section{Nutrient Digestibility}

Total-tract nutrient digestibility was estimated using lanthanum chloride as an external marker as described in Yang et al. (2017). To obtain a final dietary lanthanum concentration of $40 \mathrm{mg} / \mathrm{kg}$ of DM, $41 \mathrm{~kg}$ of the marker solution $($ density $=1.15 \mathrm{~g} / \mathrm{mL} ;[\mathrm{La}]=102$ $\mathrm{g} / \mathrm{L}$ ) was sprayed onto $1,600 \mathrm{~kg}$ of soybean meal that was incorporated into the concentrate pellets. Fecal grab samples were collected for each period across 3 consecutive days (starting on d 19) at 6-h intervals, skipping sampling times $2 \mathrm{~h}$ at the end of each day. Lanthanum concentration was determined in TMR and fecal samples by inductively coupled plasma atomic emission spectroscopy. Apparent total-tract DM digestibility and apparent total-tract nutrient digestibility were calculated using Equations 1 and 2, respectively.

$$
\begin{aligned}
& \text { DM digestibility }(\%)= \\
& 100-\frac{\text { Dietary }[\mathrm{La}](\mathrm{mg} / \mathrm{g} \text { of } \mathrm{DM})}{\text { Fecal }[\mathrm{La}](\mathrm{mg} / \mathrm{g} \text { of } \mathrm{DM})} \times 100
\end{aligned}
$$

Nutrient digestibility $(\%)=$

$$
\begin{aligned}
& 100-\frac{\text { Dietary }[\mathrm{La}](\mathrm{mg} / \mathrm{g} \text { of } \mathrm{DM})}{\text { Fecal[La }](\mathrm{mg} / \mathrm{g} \text { of } \mathrm{DM})} \\
& \times \frac{\text { Fecal }[\text { Nutrient }](\mathrm{g} / \mathrm{g} \text { of } \mathrm{DM})}{\text { Dietary }[\text { Nutrient }](\mathrm{g} / \mathrm{g} \text { of } \mathrm{DM})} \times 100
\end{aligned}
$$


YANG ET AL.

Table 1. Ingredient and chemical composition of diets (\%, DM basis)

\begin{tabular}{|c|c|c|c|c|}
\hline \multirow[b]{2}{*}{ Item } & \multicolumn{4}{|c|}{$\operatorname{Diet}^{1}$} \\
\hline & LFHD & HFHD & LFHS & HFHS \\
\hline \multicolumn{5}{|l|}{ Ingredient } \\
\hline Corn silage ${ }^{2}$ & 27.3 & 40.4 & 27.3 & 40.4 \\
\hline Alfalfa hay ${ }^{3}$ & 12.3 & 18.6 & 12.3 & 18.6 \\
\hline Hulled barley grain ${ }^{4}$ & 29.4 & 17.6 & - & - \\
\hline Hull-less barley grain ${ }^{5}$ & - & - & 29.4 & 17.6 \\
\hline Soybean meal & 15.8 & 15.8 & 15.8 & 15.8 \\
\hline Soybean meal marked & 1.8 & 1.8 & 1.8 & 1.8 \\
\hline Soybean hulls & 9.4 & 1.8 & 9.4 & 1.8 \\
\hline Calcium salts of fatty acids ${ }^{6}$ & 0.9 & 0.9 & 0.9 & 0.9 \\
\hline Sodium bicarbonate & 1.1 & 1.1 & 1.1 & 1.1 \\
\hline Bentonite & 0.9 & 0.9 & 0.9 & 0.9 \\
\hline Salt & 0.5 & 0.5 & 0.5 & 0.5 \\
\hline Magnesium oxide & 0.2 & 0.2 & 0.2 & 0.2 \\
\hline Trace mineral premix ${ }^{7}$ & 0.4 & 0.4 & 0.4 & 0.4 \\
\hline Vitamin $\mathrm{ADE}^{8}$ & 0.04 & 0.04 & 0.04 & 0.04 \\
\hline Vitamin $\mathrm{E}^{9}$ & 0.004 & 0.004 & 0.004 & 0.004 \\
\hline Rumensin $90^{10}$ & 0.007 & 0.007 & 0.007 & 0.007 \\
\hline \multicolumn{5}{|l|}{ Nutrient } \\
\hline DM, \% as fed & 57.5 & 51.4 & 56.4 & 50.4 \\
\hline $\mathrm{OM}$ & 91.6 & 92.0 & 92.3 & 92.0 \\
\hline $\mathrm{CP}$ & 16.3 & 15.9 & 15.6 & 15.3 \\
\hline NDF & 30.8 & 27.8 & 28.4 & 28.0 \\
\hline Forage NDF & 13.2 & 18.0 & 12.3 & 18.1 \\
\hline Nonforage NDF & 17.6 & 9.8 & 16.1 & 9.9 \\
\hline Starch & 23.7 & 26.4 & 26.3 & 26.5 \\
\hline Grain starch & 10.2 & 5.8 & 15.2 & 11.0 \\
\hline
\end{tabular}

${ }^{1}$ LFHD: $45 \%$ forage and hulled barley; HFHD: $65 \%$ forage and hulled barley; LFHS: $45 \%$ forage and hull-less barley; HFHS: $65 \%$ forage and hull-less barley.

${ }^{2}$ Corn silage composition: $41.7 \%$ DM, $6.0 \% \mathrm{CP}, 31.7 \% \mathrm{NDF}$, and $43.9 \%$ starch.

${ }^{3}$ Alfalfa hay composition: $90.0 \% \mathrm{DM}, 24.6 \% \mathrm{CP}, 37.8 \% \mathrm{NDF}$, and $1.8 \%$ starch.

${ }^{4}$ Hulled barley grain composition: $2.5 \%$ ash, $11.9 \% \mathrm{CP}, 36.0 \% \mathrm{NDF}$, and $37.1 \%$ starch.

${ }^{5}$ Hull-less barley grain composition: $2.7 \%$ ash, $13.3 \%$ CP, $14.0 \%$ NDF, and $53.3 \%$ starch.

${ }^{6}$ EnerGII (Virtus Nutrition LLC, Corcoran, CA).

${ }^{7}$ Contained $22.25 \%$ calcium, $7.50 \%$ magnesium, $2.75 \%$ potassium, $3.90 \%$ sulfur, $1.50 \%$ manganese, $1.50 \%$ zinc, $9,500 \mathrm{mg} / \mathrm{kg}$ of iron, $2,500 \mathrm{mg} / \mathrm{kg}$ of copper, $200 \mathrm{mg} / \mathrm{kg}$ of iodine, $200 \mathrm{mg} / \mathrm{kg}$ of cobalt, $66 \mathrm{mg} / \mathrm{kg}$ of selenium, $227,273 \mathrm{IU} / \mathrm{kg}$ of vitamin $\mathrm{A}, 136,364 \mathrm{IU} / \mathrm{kg}$ of vitamin $\mathrm{D}_{3}$, and $636 \mathrm{IU} / \mathrm{kg}$ of vitamin $\mathrm{E}$.

${ }^{8}$ Contained $3,500 \mathrm{IU} / \mathrm{kg}$ of vitamin $\mathrm{A}, 950 \mathrm{IU} / \mathrm{kg}$ of vitamin $\mathrm{D}_{3}$, and 2,000 IU $/ \mathrm{g}$ of vitamin $\mathrm{E}$.

${ }^{9}$ Contained $500 \mathrm{IU} / \mathrm{g}$ of premix.

${ }^{10}$ Contained $200 \mathrm{mg}$ of monensin/g of product (Elanco Animal Health, Indianapolis, IN).

\section{Sample Collection and Analysis}

Samples of feed ingredients and feed refusals were collected weekly. All samples were dried to constant weight at $55^{\circ} \mathrm{C}$ in a forced-air oven and ground to pass through a 1-mm screen of a Wiley mill (Thomas Scientific, Swedesboro, NJ). Ash concentration was determined after combusting samples in a furnace (Thermolyne 30400, Barnstead International, Dubuque, IA) for $3 \mathrm{~h}$ at $600^{\circ} \mathrm{C}$ (method 942.05; AOAC International, 2016). Crude protein concentration was calculated as percentage $\mathrm{N} \times 6.25$ after combustion analysis (method 990.03; AOAC International, 2016) using a Vario El Cube CN analyzer (Elementar Americas Inc., Mount Laurel, NJ). Ash-free NDF and ADF concentrations were determined using the Ankom200 Fiber Analyzer
(Ankom Technology, Macedon, NY). Sodium sulfite and $\alpha$-amylase (Ankom Technology) were included for NDF analysis (Ferreira and Mertens, 2007). Acid detergent fiber and lignin concentrations were determined sequentially. After determining ADF weights, residues were incubated for $3 \mathrm{~h}$ in $72 \%$ sulfuric acid in a 4 -L jar that was placed in a DaisyII Incubator (Ankom Technology). Starch concentration was determined using the acetate buffer method of Hall (2009) with $\alpha$-amylase from Bacillus licheniformis (FAA, Ankom Technology) and amyloglucosidase from Aspegillus niger (EAMGDF, Megazyme International, Wicklow, Ireland).

Milk samples (a.m. and p.m. milkings) were collected on d 17 and 18 for determination of milk fat, protein, lactose, and MUN concentrations with a CombiFoss FT + Fourier transform infrared analyzer (Foss, Hill- 
erød, Denmark) by United DHIA (Radford, VA). An additional milk sample (a.m. and p.m. milking) was collected on d 17 to determine milk fatty acid composition. Milk fatty acids were extracted and methylated according to the method of Chouinard et al. (1999). Fatty acid methyl esters were analyzed by gas chromatography (Agilent 6890 N GC; Agilent Technologies, Santa Clara, CA) using a CP-Sil 88 capillary column $(100 \mathrm{~m} \times 0.25 \mathrm{~mm}$ i.d. with $0.2-\mu \mathrm{m}$ thickness; Varian Inc., Palo Alto, CA). The oven temperature was initially set at $80^{\circ} \mathrm{C}$ and was increased at $2^{\circ} \mathrm{C} / \mathrm{min}$ to $190^{\circ} \mathrm{C}$ and maintained for 9 min. Inlet and flame-ionization detector temperature was $250^{\circ} \mathrm{C}$, the split ratio was $100: 1$, and a $1-\mu \mathrm{L}$ injection volume was used. The hydrogen carrier gas flow rate was $1 \mathrm{~mL} / \mathrm{min}$. Hydrogen flow to the detector was $25 \mathrm{~mL} / \mathrm{min}$, air flow was $400 \mathrm{~mL} / \mathrm{min}$, and the flow of nitrogen makeup gas was $40 \mathrm{~mL} / \mathrm{min}$. Fatty acid peaks were identified by using pure methyl ester standards (Nu-Chek Prep Inc., Elysian, MN). A butter reference standard (BCR 164; Commission of the European Communities, Community Bureau of Reference, Brussels, Belgium) was analyzed at regular intervals to determine recoveries and correction factors for individual fatty acyl composition in milk fat.

\section{Statistical Analysis}

All variables were analyzed using the MIXED procedure of SAS (SAS version 9.3, SAS Institute Inc., Cary, NC). The statistical model included the effects of square [fixed; degrees of freedom $(\mathrm{df})=5$ ], treatment (fixed; $\mathrm{df}=3$ ), square $\times$ treatment interaction (fixed; $\mathrm{df}=15)$, period (random; $\mathrm{df}=3$ ), and cow within square (random; $\mathrm{df}=18$ ) and the random residual error $(\mathrm{df}=51)$. Orthogonal contrasts were used to test the main effects of dietary forage-to-concentrate ratio (HF vs. LF) and barley type (hulled vs. hull-less) and their interaction. Differences between main effects were declared at $P<0.05$, and interactions between main effects were declared at $P<0.10$.

\section{RESULTS AND DISCUSSION}

The nutritional quality of hulled barley was poorer than expected, whereas the nutritional quality of hullless barley was proximate to expected values. Hulled barley contained (DM basis) $2.5 \%$ ash, $11.9 \% \mathrm{CP}$, $36.0 \% \mathrm{NDF}$, and $37.1 \%$ starch. The concentration of starch was 16.1 to 27.8 percentage units lower (Yang et al., 1997a; Griffey et al., 2010), whereas the concentration of NDF was 5 to 13.7 percentage units higher than previously reported values for hulled barley grains (Yang et al., 1997a; Fellner et al., 2008). Hull-less barley contained $2.7 \%$ ash, $13.3 \% \mathrm{CP}, 14.0 \% \mathrm{NDF}$, and $53.3 \%$ starch. The concentration of starch was 3.1 to 13.5 percentage units lower than previously reported values for hull-less barley grains (Yang et al., 1997a; Griffey et al., 2010). However, the concentration of NDF was 2.9 percentage units higher (Yang et al., 1997a, 2013) and 14.8 percentage units lower (Fellner et al., 2008) than previously reported values for hull-less barley grains. Differences in grain quality are likely related to differences in the growing conditions (i.e., soil and environment) between the 2 regions where barley grains were grown (Piedmont and Coastal Plains areas for hulled and hull-less barley grains, respectively).

Due to the different compositions of the barley grains and the different forage-to-concentrate ratios, dietary NDF and starch concentrations ranged from 27.8 to $30.8 \%$ and 23.7 to $26.5 \%$, respectively (Table 1). As corn silage contained a very high concentration of starch (43.9\% starch), the proportion of the total dietary starch provided by the cereal grain ranged from 21.8 to $57.7 \%$.

As the interaction between main effects tended to be significant $(P<0.13$; Table 2$)$, DMI tended to be lower for HFHD than for the rest of the diets. The reasons for this lower DMI are not clear as a slower digesta flow through the gastrointestinal tract due to greater proportions of forage particles would be expected in both HF diets (Allen, 1996; Manthey et al., 2016) independently of the type of cereal grain. However, as the digestibility of NDF was greater for HFHS than for HFHD (57.9 and 50.6\%, respectively; Table 3), it is plausible that a greater NDF digestion rate could have resulted in a faster passage rate and a shorter retention time of the digesta (Oba and Allen, 1999) for the HFHS diet, which would likely explain the differences in DMI between the $2 \mathrm{HF}$ diets.

Neither the type of barley $(P<0.75)$ nor the forageto-concentrate ratio $(P<0.34)$ affected milk yield (Table 2). As in our previous study (Yang et al., 2017), cows in the current study produced according to the aimed goals when formulating the diets, indicating that feeding barley grains as the only cereal grain source in rations for high-producing cows can sustain milk production without major drawbacks.

Even though the type of barley did not affect milk fat $(P<0.23)$ or protein $(P<0.48)$ concentrations, the fat-to-protein ratio decreased slightly in cows consuming hull-less barley $(P<0.04$; Table 2$)$. Alternatively, MUN decreased for cows consuming hull-less barley $(P$ $<0.01$ ). Although a decrease in fat-to-protein ratio in milk might suggest that rumen function was negatively affected (Slater et al., 2000), the decrease in MUN in milk might alternatively suggest that rumen function 
Table 2. Lactation performance of dairy cows consuming diets containing hulled or hull-less barley grains with different forage-to-concentrate ratios

\begin{tabular}{|c|c|c|c|c|c|c|c|c|}
\hline \multirow[b]{2}{*}{ Item } & \multicolumn{4}{|c|}{ Diet $^{1}$} & \multirow[b]{2}{*}{ SEM } & \multicolumn{3}{|c|}{$P$-value ${ }^{2}$} \\
\hline & LFHD & HFHD & LFHS & HFHS & & $\mathrm{F}$ & G & $\mathrm{F} \times \mathrm{G}$ \\
\hline Milk fat, $\%$ & 3.60 & 3.92 & 3.40 & 3.89 & 0.20 & 0.01 & 0.23 & 0.40 \\
\hline Milk fat yield, $\mathrm{kg} / \mathrm{d}$ & 1.53 & 1.63 & 1.45 & 1.57 & 0.10 & 0.03 & 0.17 & 0.81 \\
\hline Milk protein, $\%$ & 3.11 & 3.07 & 3.14 & 3.07 & 0.03 & 0.01 & 0.48 & 0.41 \\
\hline Milk lactose yield, $\mathrm{kg} / \mathrm{d}$ & 2.08 & 2.04 & 2.09 & 1.98 & 0.07 & 0.09 & 0.60 & 0.46 \\
\hline MUN, mg/dL & 15.1 & 16.0 & 13.1 & 14.8 & 1.05 & 0.01 & 0.01 & 0.37 \\
\hline Fat-to-protein ratio & 1.18 & 1.30 & 1.08 & 1.26 & 0.09 & 0.01 & 0.04 & 0.45 \\
\hline $3.5 \%$ FCM, kg/d & 43.3 & 43.9 & 42.1 & 42.9 & 1.59 & 0.43 & 0.27 & 0.93 \\
\hline Feed efficiency, $\mathrm{kg}$ of $\mathrm{FCM} / \mathrm{kg}$ of DMI & 1.61 & 1.85 & 1.64 & 1.76 & 0.10 & 0.02 & 0.74 & 0.48 \\
\hline
\end{tabular}

${ }^{1}$ LFHD: $45 \%$ forage and hulled barley; HFHD: $65 \%$ forage and hulled barley; LFHS: $45 \%$ forage and hull-less barley; HFHS: $65 \%$ forage and hull-less barley.

${ }^{2} \mathrm{~F}$ : effect of dietary forage-to-concentrate ratio; G: effect of grain type; $\mathrm{F} \times \mathrm{G}$ : interaction between $\mathrm{F}$ and $\mathrm{G}$.

was positively affected by hull-less barley (Aguilar et al., 2012). Grain type had no effect on milk fat $(P<$ $0.17)$ or protein $(P<0.88)$ yields.

Feeding LF diets decreased milk fat concentration from $3.91 \%$ to $3.50 \%(P<0.01$; Table 2$)$. These milk fat concentrations were similar to those from cows of the same genetic background, subjected to the same management, and fed diets containing $100 \%$ of the grain source as corn or hull-less barley (Yang et al., 2017). Harvatine (2017) defined diet-induced milk fat depression as a decrease in milk fat yield of up to $50 \%$ with no change in milk yield or yield of other milk components. Peterson et al. (2003) defined milk fat depression as a dramatic effect in milk fat concentration and fatty acid composition. To our knowledge, there is not a clear threshold to define what is or is not a dramatic or acute milk fat depression. Peterson et al. (2003) fed diets with very little forage and fiber (16.1\% forage and $14.9 \% \mathrm{NDF}$ ) to lactating dairy cows and reported a $27.2 \%$ decrease in milk fat yield. Based on our hypothesis, we expected a dramatic milk fat depression (>20\% difference in milk fat yield) when feeding
LF diets. However, the lower concentration of fat in milk (Table 2) resulted in only a $7 \%$ decrease in milk fat yield for cows consuming LF diets relative to cows consuming HF diets (1.49 and $1.60 \mathrm{~kg} / \mathrm{d}$, respectively). Therefore, based on the magnitude of this decrease and on the similar concentrations of de novo fatty acids in milk (Table 4), cows fed the LF diets did not show a dramatic or acute milk fat depression (Peterson et al., 2003).

Feeding LF diets increased the concentration of C18:1 trans-10 in milk fat $(P<0.01$; Table 4$)$. High concentrations of C18:1 trans-10 in milk fat were associated with reductions in milk fat concentrations in several studies (Griinari et al., 1998; Baumgard et al., 2001; Shingfield et al., 2009; Mohammed et al., 2010). Based on the concentrations of $\mathrm{C} 18: 1$ trans-10 in milk fat observed in this study, feeding LF diets with barley grains may have altered rumen function and therefore increased the production of $\mathrm{C} 18: 1$ trans-10 within the rumen. Mohammed et al. (2010) reported an association between a greater production of C18:1 trans-10 within the rumen and lower milk fat concentrations when feeding

Table 3. Apparent total-tract nutrient digestibility of dairy cows consuming diets containing hulled or hull-less barley grains with different forage-to-concentrate ratios

\begin{tabular}{|c|c|c|c|c|c|c|c|c|}
\hline \multirow[b]{2}{*}{ Item } & \multicolumn{4}{|c|}{ Diet $^{1}$} & \multirow[b]{2}{*}{ SEM } & \multicolumn{3}{|c|}{$P$-value ${ }^{2}$} \\
\hline & LFHD & HFHD & LFHS & HFHS & & $\mathrm{F}$ & G & $\mathrm{F} \times \mathrm{G}$ \\
\hline DM, $\%$ & 72.1 & 71.1 & 72.1 & 75.8 & 1.58 & 0.17 & 0.02 & 0.02 \\
\hline CP, \% & 69.0 & 71.1 & 73.3 & 77.7 & 1.45 & 0.01 & 0.01 & 0.27 \\
\hline $\mathrm{NDF}, \%$ & 55.7 & 50.6 & 51.3 & 57.9 & 2.30 & 0.66 & 0.39 & 0.01 \\
\hline Starch, \% & 99.3 & 99.1 & 99.2 & 99.4 & 0.15 & 0.88 & 0.23 & 0.03 \\
\hline
\end{tabular}

${ }^{1}$ LFHD: $45 \%$ forage and hulled barley; HFHD: $65 \%$ forage and hulled barley; LFHS: $45 \%$ forage and hull-less barley; HFHS: $65 \%$ forage and hull-less barley.

${ }^{2} \mathrm{~F}$ : effect of dietary forage-to-concentrate ratio; G: effect of grain type; $\mathrm{F} \times \mathrm{G}$ : interaction between $\mathrm{F}$ and $\mathrm{G}$. 
Table 4. Fatty acid profile ( $\mathrm{g} / 100 \mathrm{~g}$ of fat) in milk fat from dairy cows consuming diets containing hulled or hull-less barley grains with different forage-to-concentrate ratios

\begin{tabular}{|c|c|c|c|c|c|c|c|c|}
\hline \multirow[b]{2}{*}{ Fatty acid } & \multicolumn{4}{|c|}{ Diet $^{1}$} & \multirow[b]{2}{*}{ SEM } & \multicolumn{3}{|c|}{$P$-value ${ }^{2}$} \\
\hline & LFHD & HFHD & LFHS & HFHS & & $\mathrm{F}$ & G & $\mathrm{F} \times \mathrm{G}$ \\
\hline C6:0 & 1.80 & 1.94 & 1.69 & 2.00 & 0.12 & 0.01 & 0.69 & 0.15 \\
\hline C8:0 & 1.15 & 1.19 & 1.08 & 1.23 & 0.07 & 0.01 & 0.68 & 0.15 \\
\hline C10:0 & 2.98 & 2.97 & 2.80 & 3.05 & 0.16 & 0.20 & 0.66 & 0.19 \\
\hline C12:0 & 3.72 & 3.62 & 3.56 & 3.65 & 0.17 & 0.99 & 0.50 & 0.39 \\
\hline C15:0 & 1.59 & 1.38 & 1.64 & 1.29 & 0.10 & 0.01 & 0.75 & 0.23 \\
\hline C16:0 & 34.31 & 35.02 & 34.31 & 34.47 & 0.71 & 0.24 & 0.48 & 0.49 \\
\hline C16:1 (cis-9) & 3.02 & 2.78 & 3.34 & 2.44 & 0.27 & 0.01 & 0.96 & 0.05 \\
\hline C17:0 & 0.59 & 0.54 & 0.61 & 0.55 & 0.02 & 0.01 & 0.22 & 0.89 \\
\hline C18:0 & 4.73 & 5.27 & 4.58 & 5.68 & 0.26 & 0.01 & 0.42 & 0.10 \\
\hline $\mathrm{C} 18: 1$ (trans- 6 to trans- 8 ) & 0.42 & 0.37 & 0.47 & 0.35 & 0.04 & 0.01 & 0.56 & 0.05 \\
\hline $\mathrm{C} 18: 1$ (trans-9) & 0.27 & 0.25 & 0.31 & 0.24 & 0.03 & 0.01 & 0.71 & 0.19 \\
\hline $\mathrm{C} 18: 2$ (cis-9,cis-12) & 3.34 & 2.92 & 3.15 & 2.80 & 0.12 & 0.01 & 0.03 & 0.58 \\
\hline $\mathrm{C} 20: 0$ & 0.068 & 0.072 & 0.067 & 0.074 & 0.005 & 0.01 & 0.92 & 0.60 \\
\hline C18:3 (cis-9,cis-12,cis-15) & 0.34 & 0.31 & 0.32 & 0.31 & 0.03 & 0.03 & 0.20 & 0.13 \\
\hline CLA (cis-9,trans-11) & 0.44 & 0.40 & 0.47 & 0.39 & 0.06 & 0.01 & 0.75 & 0.30 \\
\hline CLA (trans-10,cis-12) & 0.014 & 0.014 & 0.017 & 0.015 & 0.008 & 0.84 & 0.67 & 0.85 \\
\hline Others & 2.77 & 2.65 & 2.91 & 2.58 & 0.09 & 0.01 & 0.35 & 0.01 \\
\hline De novo fatty acids ${ }^{3}$ & 25.22 & 25.58 & 24.54 & 25.47 & 0.68 & 0.16 & 0.43 & 0.48 \\
\hline
\end{tabular}

${ }^{1}$ LFHD: 45\% forage and hulled barley; HFHD: 65\% forage and hulled barley; LFHS: $45 \%$ forage and hull-less barley; HFHS: $65 \%$ forage and hull-less barley.

${ }^{2} \mathrm{~F}$ : effect of dietary forage-to-concentrate ratio; $\mathrm{G}$ : effect of grain type; $\mathrm{F} \times \mathrm{G}$ : interaction between $\mathrm{F}$ and $\mathrm{G}$.

${ }^{3} \mathrm{Sum}$ of $\mathrm{C} 4: 0$ to $\mathrm{C} 14: 0$.

hulled barley grains in high-starch diets ( $>35 \%$ starch). However, based on the current study and a previous study (Yang et al., 2017) in which lower dietary starch concentrations were fed, there is limited evidence to anticipate a substantial or acute milk fat depression as a consequence of an altered rumen function when feeding hull-less barley to high-producing dairy cows.

Cows consuming LF diets had greater milk protein concentrations $(3.13$ vs. $3.07 \%$ protein; $P<0.01)$ and yields $(1.33$ vs. $1.26 \mathrm{~kg} / \mathrm{d}$ of protein; $P<0.01)$ than cows consuming HF diets. It is plausible that a faster passage rate of digesta in cows consuming LF diets would increase microbial protein flow to the small intestine (Oba and Allen, 2000), therefore increasing MP availability for protein synthesis and secretion.

As an interaction between main effects was observed $(P<0.02)$, cows consuming the HFHS diet had a higher apparent total-tract DM digestibility than the rest of the cows (75.8 and $71.8 \%$, respectively; Table 3). Cows consuming diets containing hull-less barley showed greater apparent total-tract CP digestibility than cows consuming diets containing hulled barley
(75.5 and $70.1 \%$, respectively), whereas cows consuming $\mathrm{HF}$ diets showed higher apparent total-tract $\mathrm{CP}$ digestibility than cows consuming LF diets (74.4 and $71.2 \%$, respectively). An interaction between main effects was observed for apparent total-tract NDF digestibility $(P<0.01$; Table 3$)$, although the reasons for this interaction are not clear. This interaction was driven by the increased NDF digestibility for HFHS diets $(57.9 \%)$ and the decreased NDF digestibility for HFHD diets (50.6\%). Because the nutrient composition of these diets was almost identical (Table 1), differences in NDF digestibility between HF diets should be related to grain type, such as starch fermentability. However, starch was almost entirely digested in all diets $(>99 \%$ digestibility), which challenges the latter possibility. Regarding apparent total-tract starch digestibility, an interaction between main effects was also observed $(P$ $<0.01$ ), although these differences have minimum biological relevance as dietary starch was almost entirely digested.

The current study and a previous study (Yang et al., 2017) evaluated the use of hull-less barley as a grain 
source in diets for high-producing cows. Under the scope that NRC (2001) recommends increasing dietary NDF when including barley grain in diets for dairy cows (Beauchemin, 1991), both studies challenged lactation performance by formulating diets with less than 34\% dietary NDF (NRC, 2001) while ensuring adequate amounts of physically effective fiber (Mertens, 1997) through the inclusion of chopped alfalfa hay (3-5 $\mathrm{kg} / \mathrm{d}$ ). In both studies, high-producing cows performed according to aimed goals, even with LF diets. In addition, no evidence of acute milk fat depression was observed when feeding hull-less barley as the grain source in either study. Beauchemin (1991) mentioned a fat-depressing effect of high-concentrate barley-based diets. Even though our data seem to conflict with this statement, such conflict is nonexistent because in the current study and our previous study (Yang et al., 2017) the inclusion of barley in the diet was always less than 30\%, whereas in other studies (Beauchemin, 1991; Beauchemin et al., 1991) the inclusion of barley-based diets with similar NDF concentrations (i.e., $28-31 \%$ of dietary NDF) ranged from 43.1 to $54.6 \%$ (DM basis). Even though hulled and hull-less barley were the only cereal sources in the current study, their inclusion at less than $30 \%$ of the total DM may not necessarily imply that these were high-concentrate barley-based diets.

\section{CONCLUSIONS}

Feeding hulled or hull-less barley as an energy source in diets for high-producing lactating cows resulted in similar milk productions, even when feeding LF diets. However, a decrease in milk fat concentration, which resulted in a $7 \%$ decrease in milk fat yield, was observed for cows fed LF diets. In conclusion, based on the minimal effects on milk fatty acid composition, a dramatic or acute milk fat depression as a consequence of an alteration of rumen function when feeding hullless barley to high-producing dairy cows should not be expected when feeding diets containing $30 \%$ barley or less as the grain source.

\section{ACKNOWLEDGMENTS}

We are grateful to Virginia Tech (Blacksburg) undergraduate students Claire Gleason (Animal and Poultry Sciences), Victoria Prevette (Dairy Science), and Emily Richardson (Animal and Poultry Sciences) and graduate student Meng Meng Li (Dairy Science) for their help with feeding cows and collecting fecal samples. This project was funded mainly by the John Lee Pratt Endowment from the College of Agriculture and Life Sciences at Virginia Tech and partially by USDA Na- tional Institute of Food and Agriculture Hatch Project VA-160025 and USDA National Institute of Food and Agriculture Multistate Project VA-136291 (NC-2042, Management Systems to Improve the Economic and Environmental Sustainability of Dairy Enterprises).

\section{REFERENCES}

Aguilar, M., M. D. Hanigan, H. A. Tucker, B. L. Jones, S. K. Garbade, M. L. McGilliard, C. C. Stallings, K. F. Knowlton, and R. E. James. 2012. Cow and herd variation in milk urea nitrogen concentrations in lactating dairy cattle. J. Dairy Sci. 95:7261-7268.

Allen, M. S. 1996. Physical constraints on voluntary intake of forages by ruminants. J. Anim. Sci. 74:3063-3075.

AOAC International. 2016. Official Methods of Analysis. 20th ed. AOAC International, Rockville, MD.

Bauman, D. E., and J. M. Griinari. 2003. Nutritional regulation of milk fat synthesis. Annu. Rev. Nutr. 23:203-227.

Baumgard, L. H., J. K. Sangster, and D. E. Bauman. 2001. Milk fat synthesis in dairy cows is progressively reduced by increasing supplemental amounts of trans-10, cis-12 conjugated linoleic acid (CLA). J. Nutr. 131:1764-1769.

Beauchemin, K. A. 1991. Effects of dietary neutral detergent fiber concentration and alfalfa hay quality on chewing, rumen function, and milk production of dairy cows. J. Dairy Sci. 74:3140-3151.

Beauchemin, K. A., B. I. Farr, and L. M. Rode. 1991. Enhancement of the effective fiber content of barley-based concentrates fed to dairy cows. J. Dairy Sci. 74:3128-3139.

Beauchemin, K. A., L. M. Rode, and W. Z. Yang. 1997. Effects of nonstructural carbohydrates and source of cereal grain in high concentrate diets of dairy cows. J. Dairy Sci. 80:1640-1650.

Chouinard, P. Y., L. Corneau, A. Saebo, and D. E. Bauman. 1999. Milk yield and composition during abomasal infusion of conjugated linoleic acids in dairy cows. J. Dairy Sci. 82:2737-2745.

Fellner, V., J. C. Burns, and D. S. Marshall. 2008. Effect of feeding corn, hull-less or hulled barley on fermentation by mixed cultures of ruminal microorganisms. J. Dairy Sci. 91:1936-1941.

Ferraretto, L. F., P. M. Crump, and R. D. Shaver. 2013. Effect of cereal grain type and corn grain harvesting and processing methods on intake, digestion, and milk production by dairy cows through a meta-analysis. J. Dairy Sci. 96:533-550.

Ferreira, G., and D. R. Mertens. 2007. Measuring detergent fibre and insoluble protein in corn silage using crucibles or filter bags. Anim. Feed Sci. Technol. 133:335-340.

Griffey, C., W. Brooks, M. Kurantz, W. Thomason, F. Taylor, D. Obert, R. Moreau, R. Flores, M. Sohn, and K. Hicks. 2010. Grain composition of Virginia winter barley and implications for use in feed, food, and biofuels production. J. Cereal Sci. 51:41-49.

Griinari, J. M., D. A. Dwyer, M. A. McGuire, D. E. Bauman, D. L. Palmquist, and K. V. Nurmela. 1998. Trans-octadecenoic acids and milk fat depression in lactating dairy cows. J. Dairy Sci. 81:1251-1261.

Hall, M. B. 2009. Determination of starch, including maltooligosaccharides, in animal feeds: Comparison of methods and a method recommended for AOAC Collaborative Study. J. AOAC Int. 92:42-49.

Harvatine, K. J. 2017. Lipid and fat nutrition. Pages 655-666 in Large Dairy Herd Management. 3rd ed. American Dairy Science Association, Champaign, IL.

Herrera-Saldana, R., J. Huber, and M. Poore. 1990. Dry matter, crude protein, and starch degradability of five cereal grains. J. Dairy Sci. 73:2386-2393.

Manthey, A. K., K. F. Kalscheur, A. D. Garcia, and K. Mjoun. 2016. Lactation performance of dairy cows fed yeast-derived microbial protein in low- and high-forage diets. J. Dairy Sci. 99:2775-2787.

McAllister, T. A., and K.-J. Cheng. 1996. Microbial strategies in the ruminal digestion of cereal grains. Anim. Feed Sci. Technol. 62:2936.

Mertens, D. R. 1997. Creating a system for meeting the fiber requirements of dairy cows. J. Dairy Sci. 80:1463-1481. 
Mohammed, R., J. J. Kennelly, J. K. G. Kramer, K. A. Beauchemin, C. S. Stanton, and J. J. Murphy. 2010. Effect of grain type and processing method on rumen fermentation and milk rumenic acid production. Animal 4:1425-1444.

National Research Council. 2001. Nutrient Requirements of Dairy Cattle. 7th rev. ed. Natl. Acad. Press, Washington, DC.

Oba, M., and M. S. Allen. 1999. Evaluation of the importance of the digestibility of neutral detergent fiber from forage: Effects on dry matter intake and milk yield of dairy cows. J. Dairy Sci. 82:589596 .

Oba, M., and M. S. Allen. 2000. Effects of brown midrib 3 mutation in corn silage on productivity of dairy cows fed two concentrations of dietary neutral detergent fiber: 3. Digestibility and microbial efficiency. J. Dairy Sci. 83:1350-1358.

Peterson, D. G., E. A. Matitashvili, and D. E. Bauman. 2003. Diet-induced milk fat depression in dairy cows results in increased trans-10, cis-12 CLA in milk fat and coordinate suppression of mRNA abundance for mammary enzymes involved in milk fat synthesis. J. Nutr. 133:3098-3102.

Shingfield, K. J., A. Saebo, P. C. Saebo, V. Toivonen, and J. M. Griinari. 2009. Effect of abomasal infusions of a mixture of octadecenoic acids on milk fat synthesis in lactating cows. J. Dairy Sci. 92:4317-4329.

Silveira, C., M. Oba, K. A. Beauchemin, and J. Helm. 2007. Effect of grains differing in expected ruminal fermentability on the productivity of lactating dairy cows. J. Dairy Sci. 90:2852-2859.
Slater, A. L., M. L. Eastridge, J. L. Firkins, and L. J. Bidinger. 2000. Effects of starch source and level of forage neutral detergent fiber on performance by dairy cows. J. Dairy Sci. 83:313-321.

Thomason, W. E., W. S. Brooks, C. A. Griffey, and M. E. Vaughn. 2009. Hulless barley seeding rate effects on grain yield and yield components. Crop Sci. 49:342-346.

Yang, L., D. A. Christensen, J. J. McKinnon, A. D. Beattie, and P. Yu. 2013. Effect of altered carbohydrate traits in hulless barley (Hor deum vulgare $\mathrm{L}$.) on nutrient profiles and availability and nitrogen to energy synchronization. J. Cereal Sci. 58:182-190.

Yang, W. Z., K. A. Beauchemin, B. I. Farr, and L. M. Rode. 1997a. Comparison of barley, hull-less barley, and corn in the concentrate of dairy cows. J. Dairy Sci. 80:2885-2895.

Yang, W. Z., K. A. Beauchemin, K. M. Koenig, and L. M. Rode. 1997b. Comparison of hull-less barley, barley, or corn for lactating cows: Effects on extent of digestion and milk production. J. Dairy Sci. 80:2475-2486.

Yang, Y., G. Ferreira, C. L. Teets, B. A. Corl, W. E. Thomason, and C. A. Griffey. 2017. Effects of feeding hull-less barley on production performance, milk fatty acid composition, and nutrient digestibility of lactating dairy cows. J. Dairy Sci. 100:3576-3583. 